Edinburgh in 1959, he was personal assistant to Sir Ewart Smith, deputy chairman of Imperial Chemical Industries, Ltd. Prof. Cottrell's main research interest in the University of Edinburgh lies in the field of energy transfer, with particular reference to the theory of chemical reaction rates. The research school which he has built up and directed continues to investigate transfer efficiency in molecule-molecule and electron-molecule collisions: the energy transfer from low-energy electrons to rotational or vibrational modes of molecules has received special attention. In addition to research papers in the scientific journals, Prof. Cottrell's published work includes The Strength of Chemical Bonds (Butterworths), Molecular Energy Transfer in Gases (with J. C. McCoubrey) (Butterworths), Chemistry (Oxford University Press) and his recently published Dynamic Aspects of Molecular Energy States (Oliver and Boyd). At the same time, he has been actively engaged in the teaching, planning and supervision of academic programmes, with special attention to undergraduate tutorial arrangements. One major change has been the establishment in Edinburgh of an honours B.Sc. degree in chemical physics, providing chemists with a more rigorous physical and mathematical approach to the subject. Formerly a member of the University of Essex Academic Planning Board, Prof. Cottrell is now a member of the corresponding Academic Advisory Committee, and thus brings to his new post a wide experience of teaching, research, planning and administration.

Materials Science at the U.S. National Bureau of Standards: Dr. H. E. Sorrows

The U.S. National Bureau of Standards has recently announced the appointment of Dr. Howard E. Sorrows as assistant to the Director of the Institute for Materials Research. Until his appointment, Dr. Sorrows was manager of the Space and Environmental Science Programs of Texas Instruments, Inc., a position that combined scientific management with profit responsibility. From 1959 until 1963, he initiated and managed a depart. ment for technical intelligence, long-range planning, and new product development. Dr. Sorrows has previously worked at the Office of Naval Research, the Navy Bureau of Ordnance, and at the White Oak Naval Ordnance Laboratory. He began his professional career at the National Bureau of Standards. Dr. Sorrows holds degrees from Baylor University and George Washington University and a Ph.D. from Catholic University. He has been active in a number of scientific societies, including the Institute of Electrical and Electronic Engineers, the American Institute of Aeronautics and Astronautics, Sigma Pi Sigma, Sigma Xi, the Dallas-Fort Worth Council of Scientific Societies and the Metropolitan Philosophical Society. He was chairman of the Dallas Section of the Institute of Electrical and Electronic Engineers during 1964.

\section{United Kingdom Expenditure on Space Research}

IN a written answer in the House of Commons on January 25, the Secretary of State for Education and Science, Mr. A. Crosland, stated that the estimated expenditure by the Science Research Council on scientific space research in 1965-66 was $£ 3.55$ million. This included provision for the United Kingdom contribution to the European Space Research Organization of $£ 1.75$ million, most of which should be regarded as expenditure outside the United Kingdom. There was also a little expenditure outside the United Kingdom for purchase of equipment which had to be imported. In a further written answer on January 26, Mr. Crosland added that the Science Research Council organized the scientific space programme, which existed to make it possible for individual scientists, or groups of scientists, in universities or other institutions, to carry out researches in space. Hitherto, the main opportunities had been in the series of Anglo-American satellites. In future, the main opportunities would be in the European Space Research Organization and the National Aeronautics and Space Administration satellites. Also in a written answer, on January 25, the Minister of Technology, Mr. F. Cousins, stated that under its contract with the European Space Research Organization, the Atomic Energy Authority had completed its design study of the payload for the astronomical satellite project in which it makes proposals for satellite-borne instruments to enable ultra-violet and X-ray studies to be made of stars and nebulae. The Authority's design would be in competition with two other contract studies requested by the Organization, which was expected to take several months to assess them. In a further written answer, on January 27, the Minister of Aviation, Mr. F. Mulley, stated that the total estimated expenditure in $1965-66$ by the United Kingdom on the sp $z$ ce programme amounted to about $£ 22$ million, or 0.07 per cent of the gross national product, or a per capita expenditure of $5 s .6 d$. compared with $1 s$. in Belgium, $9 s$. $6 d$. in France, $6 s$. in the Federal Republic of Germany, and $2 s .3 d$. in The Netherlands. About 3,800 persons in the United Kingdom were employed on the British space programme and $£ 1.5 .32$ million was provided in the 1965-66 programme for expenditure by the Ministry of Aviation on space research and development. This did not include expenditure to meet specific requirements of the Ministry of Defence and the Science Research Council, but does include a net payment of $£ 2.21$ million for the European Launcher Development Organization transactions.

\section{Forestry Commission: Plans for Expansion}

IN reply to a question in the House of Lords on February 3, Lord Mitchison, Joint Parliamentary Secretary to the Minister of Land and Natural Resources, said that the Government had completed its review of planting to be carried out by the Forestry Commission. The programme for Great Britain provided for the Commission to plant 450,000 acres during the years $1964-73$ and it had been decided that planting in England and Wales should continue within this programme. In Scotland it had been decided, in view of circumstances set out in the White Paper on the Scottish Economy, 1965 to 1970 (Cmnd. 2864), to increase the programme from the present level of 30,000 acres a year to 36,000 acres a year from 1969. In a written answer in the House of Commons on February 2, the Secretary of State for Scotland, Mr. W. Ross, stated that the Forestry Commission intended, as soon as circumstances permitted, to increase the number of professional, scientific and supporting staff in Edinburgh from seventeen to about forty. The location of the new building required was already being considered.

\section{United Kingdom Atomic Energy Authority: Non- nuclear Research}

Is a written answer in the House of Commons on February 3, the Minister of Technology, Mr. F. Cousins, stated that scientific effort of the Atomic Energy Authority on work not directly connected with nuclear energy was equivalent to that of about eighty professionally qualified or graduate scientists and engineers.

\section{United States-Poland Exchange Programme}

The U.S. National Academy of Sciences and the Polish Academy of Sciences have announced plans for a programme of exchange visits by scientists of the two countries. The agreement, which covers a 3-year period, became effective from January 1 and provides for exchanges in all the disciplines in which the two Academies are mutually competent: natural sciences, including mathematics; engineering sciences; and behavioural sciences. The new programme is flexible in its provisions 